\title{
MAKALAH \\ DINAMIKA PEMBELAJARAN SEJARAH \\ DALAM PEMIKIRAN EROPA
}

Diajukan untuk memenuhi tugas Mata Kuliah Sejarah Eropa (AKBK1206)

\section{Dosen Pengampu}

Dr. Mohamad Zaenal Arifin Anis, M.Hum.

Mansyur, S.Pd., M.Hum.

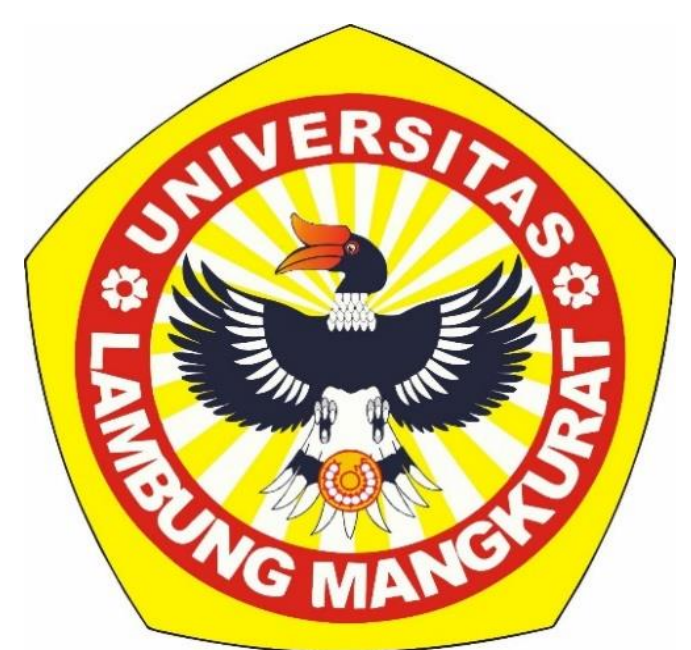

Disusun Oleh:

Kelompok I

FATIMATUZ'ZHINTA ZAHRA PUTRI (A2)

PROGRAM STUDI PENDIDIKAN SEJARAH JURUSAN PENDIDIKAN ILMU PENGETAHUAN SOSIAL FAKULTAS KEGURUAN DAN ILMU PENDIDIKAN UNIVERSITAS LAMBUNG MANGKURAT BANJARMASIN 


\section{KATA PENGANTAR}

Dengan memanjat puji syukur kehadirat Tuhan Yang Maha Esa atas karunia dan rahmat-Nya, penulis dapat menyusun makalah yang berjudul "Dinamika Pemikiran Eropa Di Dalam Pembelajaran Sejarah" dengan lancar dan tepat waktu.

Penulis mengucapkan terima kasih sebesar-besarnya kepada Dr. Mohamad Zaenal Arifin Anis, M.Hum., dan Mansyur, S.Pd., M.Hum. selaku dosen mata kuliah Sejarah Eropa atas tugas yang telah diberikan sehingga dapat menambah pengetahuan dan wawasan terkait dengan bidang yang ditekuni. Penulis juga berterima kasih kepada pihak - pihak yang telah membantu menyelesaikan makalah ini.

Penulis menyadari bahwa masih banyak kekurangan dan kekeliruan dalam penulisan makalah ini, baik pada teknis penulisan maupun materi yang disajikan. Tegur sapa dari pembaca akan penulis terima dengan tangan terbuka demi perbaikan dan penyempurnaan makalah ini.

Banjarmasin, 8 Mei 2021

Penulis 


\section{DAFTAR ISI}

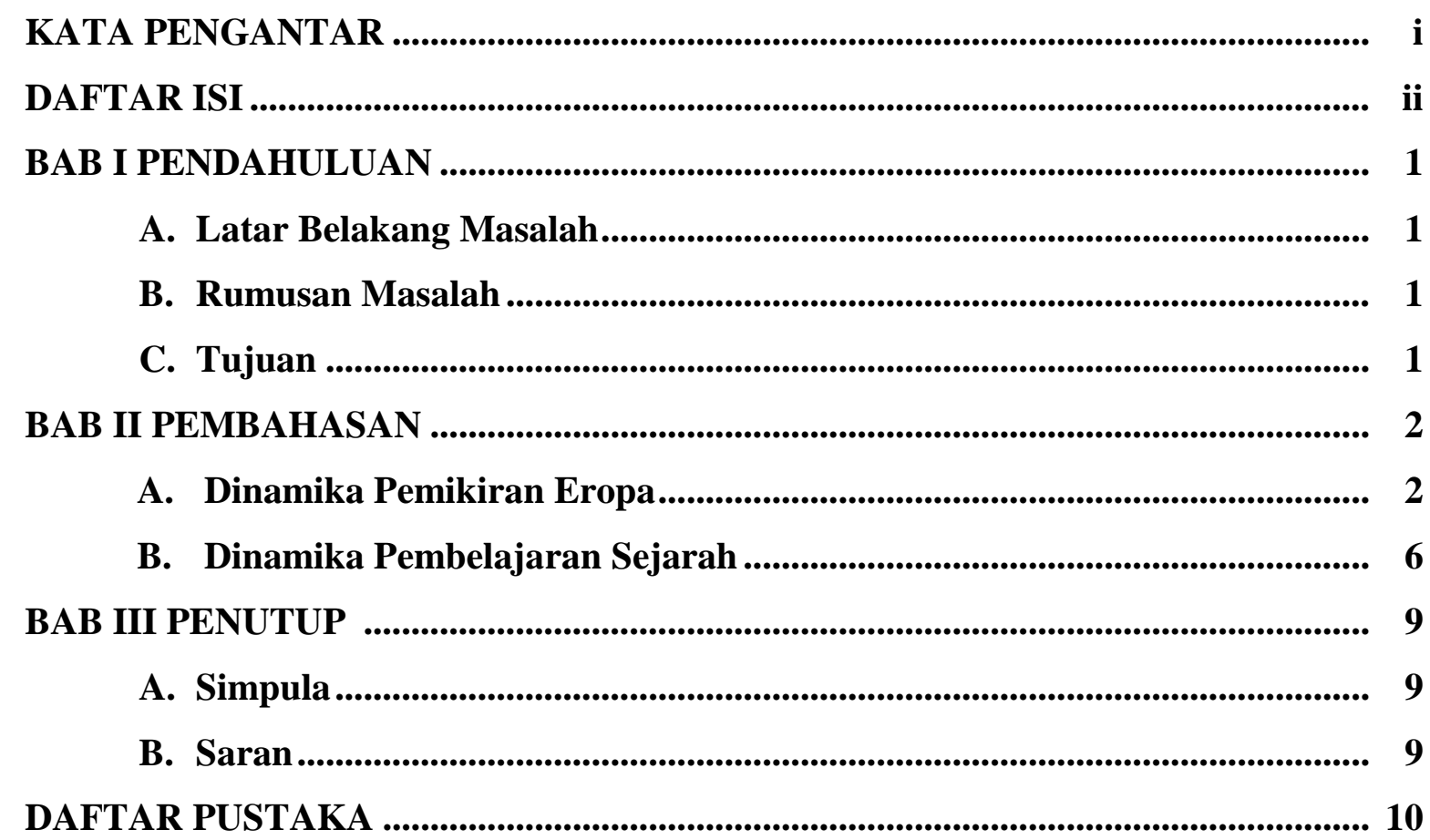




\section{BAB I}

\section{PENDAHULUAN}

\section{A. Latar Belakang Masalah}

Perkembangan perubahan eropa pada saat dulu sampai dengan sekarang masih sangat mempengaruhi terhadap pemikiran-pemikiran yang ada di bangsa eropa. Dimana pemikiran-pemikiran tersebut menimbulkan tokoh-tokoh pemikir pada masa eropa diantaranya seperti Agustinus, John Locke, Monstesquieu, J.J. Rousseau, Thomas Aquinas dan tokoh pemikir lainnya yang sangat berpengaruh terhadap perkembangan eropa pada saat itu. Seiring dengan adanya pemikiran dan perkembangan di eropa, maka pemikir dari eropa membawa pengaruh terhadap perkembangannya salah satu diantaranya yaitu terjadi proses dinamika pemikiran Eropa dalam pembelajaran sejarah khususnya pada bidang pendidikan. Dimana dinamika pemikiran pembelajaran sejarah sangat berpengaruh terhadap proses pembelajaran terutama bagi guru dan siswa. Oleh karena itu dalam makalah ini akan dibahas lebih mendalam lagi tentang "Dinamika Pemikiran Eropa Di Dalam Pembelajaran Sejarah". Perkembangan perubahan eropa pada saat dulu sampai dengan sekarang masih sangat mempengaruhi terhadap pemikiran-pemikiran yang ada di bangsa eropa. Adanya pemikiran dan perkembangan di eropa, membawa pengaruh terhadap perkembangannya salah satu diantaranya yaitu terjadi proses dinamika pemikiran Eropa seperti Renaissance dan Aufklarung yang sangat berpengaruh pada masa itu. Selain itu, terjadi juga Dinamika Pembelajaran sejarah khususnya pada bidang pendidikan. Dimana dinamika pemikiran pembelajaran sejarah sangat berpengaruh terhadap proses pembelajaran terutama bagi guru dan siswa. Selain itu keberhasilan kegiatan belajar mengajar bergantung juga pada sumber mata pembelajaran dan dan media pembelajaran. Pembelajaran yang berkualitas sangat tergantung dari motivasi pelajar dan kreativitas pengajar dalam keberhasilan pencapaian target belajar.

\section{B. Rumusan Masalah}

1. Bagaimana terjadinya proses dinamika pemikiran Eropa di dalam pembelajaran sejarah?

2. Mengapa dinamika Pemikiran Eropa termasuk dalam pembelajaran sejarah?

\section{Tujuan}

1. Untuk mengetahui proses dinamika pemikiran Eropa di dalam pembelajaran sejarah.

2. Untuk mengetahui dinamika pemikiran Eropa termasuk dalam pembelajaran sejarah. 


\section{BAB I}

\section{PEMBAHASAN}

\section{A. DINAMIKA PEMIKIRAN EROPA}

\section{Renaissance}

Abad pertengahan merupakan abad kebangkitan religi di Eropa.Runtuhnya kebudayaan abad pertengahan disusul oleh periode pertentangan pemisahan dan perubahan-perubahan secara mendalam dalam bidang politik, ekonomi dan agama.

a. Latar belakang terjadinya Renaissance

Untuk menjelaskan latar belakang terjadinya Renaissance, kita harus tahu bagaimana keadaan Eropa pada periode Dark Age atau abad kegelapan. Mengapa disebut abad kegelapan? Hal ini disebabkan pada masa ini berkembang anggapan bahwa ilmu pengetahuan harus dilandasi oleh agama. Oleh sebab itu munculah pembatasanpembatasan dalam mengembangkan pemikiran maupun ilmu pengetahuan. Anggapan ini menyebabkan gereja mendominasi seluruh aspek kehidupan seperti bidang pemerintahan, ekonomi, pendidikan dan sosial budaya. Gereja mempengaruhi berbagai kebijakan yang dibuat oleh pemerintah sehingga raja tidak memiliki kekuasaan dalam kegiatan pemerintahan. Seluruh kegiatan masyarakat atau rakyat dilakukan untuk kepentingan gereja. Kegiatan tersebut akan berjalan baik jika sesuai dengan kehendak gereja. Jika ada hal yang dianggap merugikan kepentingan gereja, maka akan mendapat balasan yang setimpal dengan apa yang diperbuat. Sebagai contoh: pemberian hukuman kepada Nicolaus Copernicus (1473-1543) yang menyebutkan matahari adalah pusat tata surya, hal ini bertentangan dengan ajaran gereja sehingga Copernicus dijatuhi hukuman mati. Doktrinasi dan dominasi gereja di Eropa pada abad pertengahan dianggap merugikan sehingga kemudian muncullah suatu gerakan yang ingin mempelajari ilmu pengetahuan dan terbebas dari belenggu kekuasaan gereja. Gerakan inilah yang disebut Renaissance. Disamping latar belakang diatas, juga ada latar belakang ekonomi, dimana sebelum Renaissance di Eropa berlaku sistem ekonomi tertutup. Sistem ekonomi yang mana penguasa perekonomian hanya golongan penguasa. Kondisi ini menyebabkan kehidupan masyarakat terkungkung dan tidak memiliki harga diri yang layak sebagai manusia.

b. Pengertian Renaissance

Sebelum menjelaskan pengertian Renaissance, kita harus mengerti istilah Renaissance.istilah ini berasal dari bahasa latin yaitu renaitre yang berarti hidup kembali atau kelahiran kembali. Secara umum pengertian Renaissance adalah kelahiran atau hidupnya kembali kebudayaan klalik Yunani dan Romawi dalam kehidupan masyarakat Eropa atau Barat. Renaissance merupakan suatu masa atau periode yang berlangsung kira-kira abad ke--14 sampai abad ke-17, yang dimulai dari Italia dan kemudian menyebar ke seluruh Benua Eropa. Gerakan ini secara bersamaan dan persebaran gerakan ini ditandai dengan pemakaian kertas dan penemuan barang metal. Jules Michelet (17981874) merupakan seorang sejarawan yang pertama kali mendefinisikan dan memperkenalkan istilah Renaissance dalam karyanya yang berjudul Histoire de France. Jules Michelet adalah seorang sejarawan Prancis. Ia 
dilahirkan di Paris dari keluarga dengan tradisi Huguenot. Ia lahir pada tanggal 21 Agustus 1798, Paris, Perancis dan meninggal: 9 Februari 1874, Hyëres, Perancis Pasangan: Athénaïs Michelet (m. 18491874).Tokoh-Tokoh Renaissance dan pemikirannya Titik awal dari peradaban modern Eropa adalah peristiwa Renaissance. Dengan munculnya periode Renaissance, perspektif manusia di Barat mulai berubah. Sebelum adanya Renaissance, pandangan masyarakat hanya mementingkan kehidupan akhirat. Setelah itu pandangan masyakat berubah menjadi juga memikirkan hidupnya di dunia ini. Periode atau zaman Renaissance juga disebut zaman humanisme. Mengapa disebut demikian? Sebelum menjelaskan tentang pemikiran para tokoh masa Renaissance kita akan membahas tentang apa itu humanisme? Humanisme adalah sebuah pemikiran filsafat yang mengedepankan nilai dan kedudukan manusia serta menjadikannnya sebagai kriteria dalam segala hal. Humanisme telah menjadi sejenis doktrin beretika yang cakupannya diperluas hingga mencapai seluruh etnisitas manusia. Humanisme menghendaki ukuran haruslah dari manusia. Karena manusia mempunyai kemampuan berpikir, maka humanisme menggapa manusia mampu mengatur dirinya dan dunia. Kemuliaan manusia terletak dalam kebebasannya untuk menentukan pilihan sendiri dan dalam posisinya sebagai penguasa atas alam (Pico Della Mirandorla). Secara garis besar ciri utama dari Renaissance adalah humanisme (memanusiakan manusia), empirisme (kebebasan pengembangan ilmu pengetahuan) dan rasionalisme (kebebasan dalam mengembangkan fikiran). Untuk memudahkan pembelajaran, maka tokoh-rokoh Renaissance dibagi berdasarkan bidang keahliannya yaitu bidang seni dan budaya, bidang penjelajahan samudera, dan bidang ilmu pengetahuan.

- Bidang seni dan budaya

$>$ Albrect Duhrer (1471-1528)

$>$ Desiderius Erasmus (1466-1536)

$>$ Donatello - Ghirlandaio - Hans Holbein (1465-1506)

$>$ Hans Memling (1430-1495)

$>$ Hieronymus Bosch (1450-1516)

$>$ Josquin De Pres (1445-1521)

$>$ Leonardo Da Vinci (1452-1519) - Dan Lain-lain

- Bidang penjelajahan samudera

Renaissance menyebabkan kemajuan dalam bidang ilmu pengetahuan dan teknologi yang menghasilkan temuan-temuan baru, misalnya temuan Nicolaus Copernicus bahwa bumi itu bulat. dan ditemukanya teknologi kompas.Hal ini mendorong pelautpelaut dari Spanyol, Portugis dan negaranegara Eropa lainnya untuk berlayar menjelajahi samudera mencari daerah baru. - Christopher Colombus (1451-1506) - Ferdinand Magellan (1480-1521).

- Bidang ilmu pengetahuan

$>$ Nicolaus Copernicus (1478-1543)

Nicolaus Koppernigk adalah seorang astronom, matematikawan, dan ekonom berkebangsaan Polandia, yang mengembangkan teori heliosentrisme Tata Surya dalam bentuk yang terperinci, sehingga teori tersebut bermanfaat bagi sains. Ia juga seorang kanon gereja, gubernur dan administrator, hakim, astrolog, dan tabib. Lahir : 19 Februari 1473, Toruń, Polandia Meninggal : 24 
Mei 1543, Frombork, Polandia Pendidikan : Universitas Padova (1501-1503), LAINNYA Dikenal sebagai : Heliosentrisme, Teori kuantitas uang, Hukum Gresham Orang Tua : Barbara Watzenrode, Nicolaus Copernicus Sr.

$>$ Johan Gutenberg (1400-1468)

$>$ Andreas Vesalius (1514-1564)

$>$ William Gilbert (1540-1603)

$>$ Galileo Galilei (1546-1642)

> Johannes Kepler (1571-1642)

c. Pengaruh Renaissance terhadap dunia dan Indonesia

Periode Renaissance yang terjadi di Eropa telah membawa berbagai perubahan yang besar dalam berbagai bidang kehidupan. Perubahan ini membawa dampak terhadap dunia termasuk Indonesia. Salah satu pengaruh adanya Renaissance adalah muncullah pembaharuan dan penemuan baru yeng terkenal ke berbagai penjuru dunia. Beberapa contoh penemuan yang berpengaruh hingga saat ini diantaranya adalah:

- Nicolaus Copernicus merupakan seorang astronom, matematikawan, dan ekonom. Copernicus mengembangkan Teori Heliosentris

- Johannes Kepler adalah astronom, matematikawan dan astrolog. Johannes Kepler berkebangsaan Inggris. Ia menemukan Hukum Kepler.

- Galileo Galilei adalah astronom, filsuf, dan fisikawan. Ia menyempurnakan penemuan teleskop dan mengadakan berbagai observasi tentang ilmu astronomi.

Salah satu pengaruh dari Renaissance adalah terjadinya kegiatan invasi secara besar-besaran bangsa Barat ke Dunia Timur termasuk Indonesia. Kegiatan invasi ini dipengaruhi oleh penemuan pada masa Renaissance diantaranya penemuan mesin cetak oleh Johann Gutenberg, senjata api, dan penemuan kompas yang digunakan untuk menentukan arah mata angin dalam pelayaran. Periode Renaissance yang terjadi di Eropa telah membawa berbagai perubahan yang besar dalam berbagai bidang kehidupan. Perubahan ini membawa dampak terhadap dunia termasuk Indonesia. Salah satu pengaruh adanya Renaissance adalah muncullah pembaharuan dan penemuan baru yeng terkenal ke berbagai penjuru dunia.

\section{Aufklarung}

Aufklarung dikenal juga dengan zaman pencerahan. Aufklarung merupakan suatu periode atau zaman yang merupakan kelanjutan dari zaman Renaissance. Menurut pendapat para tokoh yang mempelopori terjadinya zaman pencerahan akal dan budi manusia harus digunakan untuk menjawab masalah kehidupannya. Terjadinya zaman ini telah memberikan kontribusi yang sangat besar bagi perubahan dalam sejarah Eropa dan bahkan sejarah dunia. Salah satu peristiwa besar yang dipengaruhi oleh Aufklarung adalah Revolusi Perancis (1789) yang ikut serta mempengaruhi tatanan masyarakat dunia. Setelah sebelumnya kita mempelajari tentang Renaissance, kini kita lanjutkan pembahasan mengenai Aufklarung yang merupakan kelanjutan dari Renaissance.

a. Pengertian Aufklarung

Aufklarung adalah kata Jerman yang berpadanan dengan kata Inggris enlightenment yang berarti pencerahan, penerangan. Aufklarung adalah suatu masa Aufklarung adalah suatu gerakan besar di Eropa yang terjadi 
pada abad ke-18 M yang memberikan kedudukan luar biasa terhadap akal dan budi manusia. Masa Aufklarung merupakan istilah yang digunakan untuk menggambarkan aliran utama pemikiran abad ke-18 di Eropa dan Amerika. Pada masa pencerahan, pendekatan berdasarkan rasio dan ilmu pengetahuan terhadap agama, sosial, ekonomi dan plitik menjadi tren di masyarakat, sehinga hal ini menghasilkan pandanganan yang bersifat duniawi atau sekuler. Pandangan ini kemudian membangun opini umum tentang kemajuan dan kesempurnaan di berbagai bidang. Semua ini tidak terlepas dari pengaruh perkembangan ilmu pengetahuan dan intelektual yang sangat menjunjung tinggi prinsip universal dan kepercayaan terhadap hukum alam, dimana perkembangan itu pun menumbuhkan rasa kepercayaan terhadap akal manusia.

b. Latar belakang penyebab terjadinya Aufklarung

Kalau Renaissance dipandang sebagai peremajaan pikiran, maka Aufklarung mejadi masa pendewasaannya. Periode ini telah banyak membawa perubahan pola pikir manusia. Manusia mulai menggunakan akalnya untuk meneliti secara kritis segala sesuatu dalam kehidupannya termasuk dalam kehidupan bernegara. Pada abad pertengahan di Eropa terjadi perubahan dan perkembangan ilmu pengetahuan yang menggunakan metode ilmiah yang menjadi landasan dalam merumuskan persoalan dan solusi. Metode ilmiah ini menggunakan hipotesis, eksperimen (percobaan), dan observasi (pengamatan. Metode ilmiah inilah yang menggantikan pendekatan ilmiah sebelumnya yang berdasarkan kepercayaan atau tradisi. Ilmuwan Sir Isaac Newton (1687) merupakan peletak dasar bagi terjadinya Aufklarung. Dengan karyanya yang berjudul Philosophiae naturalis principia mathematica (ilmu pengetahuan alam berdasarkan prinsip-prinsip matematis) telah berpengaruh terhadap berkembangnya ilmu pengetahuan.

c. Pemikiran tokoh-tokoh Aufklarung.

$>$ Rasionalisme

Secara umum, rasionalisme merupakan pendekatan filosofis yang menekankan aka budi atau rasio sebagai sumber utama pengetahuan. Hampir semua ahli yang muncul pada masa ini adalah ahli matematika. Seperti Descartes, Spinoza, dan Leibniz.

$>$ Empirisme

Aliran pemikiran ini adalah lawan dari rasionalisme yang menganggap bahwa sumber pengetahuan harus dicari dalam pengalaman. Pengalaman inderawi menurut mereka merupakan saru-satunya sumber pengetahuan, bukan akal. Aliran ini diawali oleh Francis Bacon (1561-1626) yang memberi penekanan pada pengalaman sebagai sumber pengenalan. Aliran ini kemudian dikembangkan oleh Thomas Hobbes (1588-1679), John Locke (1632-1704) dan D. Hume (1711-1776).

$>$ Kantianisme

Aliran ini mencoba menggabungkan dua aliran yaitu rasionalisme dan empirisme. Tokoh yang terkenal dari aliran ini adalah Immanuel kant. Menurut Kant, pengetahuan adalah kerja sama dua unsur, yaitu pengalaman dan kearifan akal budi.

$>$ Idealisme

Menurut aliran ini pengetahuan deduktif dapat diperoleh manusia dengan akalnya. Beberapa tokoh dalam aliran ini adalah J.G. Fitche 
(1762-1914), F.W.S. Schelling (1775-1854), dan F. Hegel (17701831). Positivisme Aliran ini hanya menyempurnakan aliran empirisme dan rasionalisme. Pada dasarnya aliran ini sama dengan empirisme dan rasionalisme, hanya perbedaan nya empirisme menerima pengalaman batin sedangkan positivisme membatasi pada pengalaman objektif saja. Pelopor utama aliran ini adalah Auguste Comte (1798-1857).

$>$ Pragmatisme

Pragmatisme adalah aliran pemikiran yang memandang bahwa benar tidaknya suatu ucapan, dalil, atau teori, semata-mata bergantung kepada manfaatnya dalam kehidupan. Salah satu tokohnya adalah William James (1842-1910). Dalam bukunya The Meaning of Truth, ia mengatakan tidak ada kebenaran mutlak, berlaku umum dan berdiri lepas dari akal.

$>$ Fenomenologi

Fenomenologi adalah sebuah studi dalam bidang filsafat yang mempelajari manusia sebagai sebuah fenomena. Ilmu ini berhubungan dengan hermeneutik yaitu ilmu yang mempelajari arti dari fenomena ini. Ahli fenomenologi yang pertama adalah Edmund Husserl (1859- 1938). Tulisan Husserl yang menarik adalah Logical Investigation (1900-1901), Idea for a Pure Phemenology (1913) dan Corestian Meditations (1929).

$>$ Eksistensialisme

Eksistensialisme merupakan aliran filsafat yang memandang gejala dengan berdasar pada eksistensinya. Menurut aliran ini bagaimana manusia berada (bereksistensi) dalam dunia. Pusat perhatian aliran ini adalah situasi manusia. Istilah Eksistensialisme dikemukakan oleh ahli filsafat Jerman Martin Heidegger (1889-1976).

d. Pengaruh Aufklarung

Pengaruh Aufklarung sangat dirasakan pada perkembangan teknologi dan pemikiran abad modern. Selain itu, masa aufklarung juga menghasilkan beberapa filsafat penting yang masih diadopsi sampai saat ini dalam berbagai ilmu pengehuan. Secara garis besar pengaruh Aufklarung bagi dunai terbagi menjadi dua yaitu pengaruh dibidang pemikiran dan teknologi. Dibidang pemikiran, munculnya zaman aufklarung telah menyebabkan berkembangnya paham liberalisme dan nasionalisme. Aufklarung mengedepankan dan memaksimalkan kemampuan akal manusia, kemudian mendorong munculnya berbagai ideologi baru. Sedangkan dibidang ilmu pengetahuan dan teknologi, mulai bermunculan penemuan-penemuan baru dalam bidang ilmu pengetahuan dan teknologi yang berhasil merevolusi bidang iptek di Eropa dan bermanfaat sampai saat ini.

\section{B. DINAMIKA PEMBELAJARAN SEJARAH}

Arifin Anis, M.Z. (2015) "Sejarah Bukan Warisan Melainkan Pembelajaran." Artikel ini membahas bahwa sejarah adalah sebuah pembelajaran bukan warisan. Ada banyak definisi sejarah, dan secara konseptual dalam kajian ini menguraikan dua aspek kajian utama, yaitu sejarah dan pendidikan sejarah dan berpikir historis dan model-model pembelajaran sejarah. Berdasarkan dari kedua aspek artikel tersebut, memberikan penegasan bahwa sejarah bertalian dengan kognitif dalam 
berpikir historis sehingga akan terlihat dialog antara masa lampau, masa sekarang, dan masa yang akan datang.

Kata sejarah berasal dari bahasa Arab asyajara berarti terjadi syajarah berarti pohon, syajarahan- nasab berarti pohon silsilah, apabila dialihbahasakan kedalam bahasa Inggris history yang berasal dari bahasa Latin dan Yunani yaitu historia. Dakam bahasa Yunani disebut istoria ketika digunakan oleh para ilmuwan dari Ionia (salah satu provinsi Yunani di Asia Muka), seperti Hecatheus 500 SM.

Hakekat sejarah menurut Kontowijoyo sebagai mana dikutip oleh (Arifin Anis, 2015: 58), sejarah adalah memanjang dalam waktu terbatas dalam ruang. Pandangan ini pada dasarnya mengkritisi pandangan Dilthey seorang pakar yang mempioniri tentang pendekatan geisteswissenschten (ilmu humaniora) dengan hermeneutiknya. Hemat Kontowijoyo kekurangan Dilthey, ia melupakan, bahwa sejarah merupakan sebuah proses. Kekurangan Dilthey menurut Kuntowijoyo sudah ditutupi oleh karya oleh Galtung. Tampaknya Kontowijoyo mengimani apa yang dilontarkan oleh Galtung. Menurut Galtung seperti yang saya kutip dari Kontowijoyo ilmu sejarah adalah diakronis, sebab ia memanjang dalam waktu, tetapi dalam ruang yang terbatas, sedangkan ilmu sosial lain (antropologi, sosiologi, politik, hukum dan sebagainya) adalah ilmu sinkronis, yang meneliti fenomena yang meluas dalam ruang dan menyempit dalam waktu.

Mengutip dari Jurnal "Pelatihan Penyusunan Perangkat Pembajaran Mata Pelajaran Sejarah Kurikulum 2013" bahwa pembelajaran adalah proses interaksi peserta didik dengan pendidik dan sumber belajar pada suatu lingkungan belajar. Pembelajaran merupakan bantuan yang diberikan pendidik agar dapat terjadi proses perolehan ilmu pengetahuan, penguasaan kemahiran dan tabiat, serta pembentukan sikap dan kepercayaan pada peserta didik. Dengan kata lain, pembembelajaran adalah proses untuk membantu peserta didik agar dapat belajar dengan baik.

Disisi lain pembelajaran sejarah mempunyai pengertian yang mirip dengan pengajaran, tetapi sebenarnya mempunyai konotasi yang berbeda. Dalam konteks pendidikan, guru mengajar agar peserta didik dapat belajar dan menguasai isi pembelajaran hingga mencapai sesuatu objektif yang ditentukan (aspek kognitif), juga dapat mempengaruhi perubahan sikap (aspek afektif), serta keterampilan (aspek psikomotor) seorang peserta didik, namun proses pengajaran saja. Sedangkan pembelajaran menyiratkan adanya interaksi antara pengajar dengan peserta didik.

Adapun menurut Taufik Abdullah pelajaran sejarah bukan rentetan peristiwa yang kering dan partikular tetapi sebuah wacana intelektual yang kritis dan rasional. Pembelajaran sejarah harus melalui tahapan sebagai berikut: (1) memupuk kesadaran sosial dan keakraban, (2) memperkenalkan makna dimensi waktu dalam dinamika kehidupan kepada siswa dan rasa hayat sejarah. Meteri pembelajaran sejarah jangan didominasi oleh sejarah politik melainkan sejarah sosial yang berisikan kreativitas lokal, (3) sejarah diajarkan sebagai kegiatan akademis untuk memahami jiwa dari sebuah perubahan.

Pembelajaran yang berkualitas sangat tergantung dari motivasi pelajar dan kreativitas pengajar. Pembelajaran yang memiliki motivasi tinggi ditunjung dengan pengajar yang mampu memfasilitasi motivasi tersebut akan membawa pada keberhasilan pencapaian target belajar. Target belajar dapat diukur melalui perubahan sikap dan kemampuan siswa melalui proses belajar.

Selain itu keberhasilan kegiatan belajar mengajar bergantung juga pada sumber mata pembelajaran dan dan media pembelajaran. Jika sumber- 
sumber pembembelajaran dipilih dan disiapkan dengan lebih hati-hati dapat memenuhi tujuan pembelajaran (Anis, 2013: 9).

Mengutip dari jurnal " Sejarah Sebagai Sumber Pembelajaran Sejarah" bahwa pembelajaran sejarah merupakan perpaduan antara pembembelajaran itu sendiri dengan ilmu sejarah, yang mans keduanya tetap memperhatikan tujuan utama pendidikan secara umum. Pemerintah sebagai pemegang otoritas pendidikan berpendapat tentang tujuan dari mata pelajaran sejarah melalui Peraturan Menteri Pendidikan Nasional. Menurut Peraturan Menteri Pendidikan Nasional Republik Indonesia Nomor 22 tahun 2006 tentang standar isi tercantum dalam lampiran Peraturan Menteri, bahwa mata pelajaran sejarah bertujuan agar peserta didik memiliki kemampuan sebagai berikut:

1. Membangun kesadaran peserta didik tentang pentingnya waktu dan tempat yang merupakan sebuah proses dari mada lalu, masa kini, dan masa depan.

2. Melatih daya kritis peserta didik untuk memahami fakta sejarah secara benar dengan didasarkan pada pendekatan ilmiah dan metodologi keilmuan.

3. Menumbuhkan apresiasi dan penghargaan peserta didik terhadap peninggalan sejarah sebagai bukti peradaban bangsa Indonesia di masa lampau.

4. Menumbuhkan pemahaman peserta didik terhadap proses terbentuknya bangsa Indonesia melalui yang panjang dan masih berproses hingga masa kini dan masa yang akan datang.

5. Menumbuhkan kesadaran dalam diri peserta didik sebagai bagian dari bangsa Indonesia yang memiliki rasa bangga dan cinta tanah air yang dapat diimplementasikan dalam berbagai bidang kehidupan baik nasional maupun internasional.

Pembelajaran sejarah mengacu pada mencari, menemukan memverifikasikan maka diperlukan kemampuan berpikir historis bagi guru dan siswa. Melalui kemampun berpikir historis maka output pembelajaran sejarah sosok siswa yang memiliki kemampuan untuk memperoleh nilai-nilai dari sejarah. 


\section{BAB III}

PENUTUP

\section{A. Kesimpulan}

Renaissance abad pertengahan merupakan abad kebangkitan religi di Eropa. Secara umum pengertian Renaissance adalah kelahiran atau hidupnya kembali kebudayaan klasik Yunani dan Romawi dalam kehidupan masyarakat Eropa atau Barat. Latar belakang terjadinya Renaissance yaitu keadaan Eropa pada periode Dark Age atau abad kegelapan. Hal ini disebabkan pada masa ini berkembang anggapan bahwa ilmu pengetahuan harus dilandasi oleh agama. Oleh sebab itu munculah pembatasanpembatasan dalam mengembangkan pemikiran maupun ilmu pengetahuan. Selain itu, ada juga disebabkan oleh latar belakang ekonomi, dimana sebelum Renaissance di Eropa berlaku sistem ekonomi tertutup. Sistem ekonomi yang mana penguasa perekonomian hanya golongan penguasa. Kondisi ini menyebabkan kehidupan masyarakat terkungkung dan tidak memiliki harga diri yang layak sebagai manusia. Tokoh-rokoh Renaissance diantaranya Albrect Duhrer, Desiderius Erasmus, Donatello, Hans Memling, Josquin De Pres, leonardo Da Vinci, Christopher Colombus, Ferdinand Magellan, dan Nicolaus Copernicus

Aufklarung adalah suatu gerakan besar di Eropa yang terjadi pada abad ke-18 M yang memberikan kedudukan luar biasa terhadap akal dan budi manusia. Aufklarung dikenal juga dengan zaman pencerahan. Aufklarung merupakan suatu periode atau zaman yang merupakan kelanjutan dari zaman Renaissance. Latar belakang penyebab terjadinya Aufklarung Kalau Renaissance dipandang sebagai peremajaan pikiran, maka Aufklarung mejadi masa pendewasaannya. Periode ini telah banyak membawa perubahan pola pikir manusia. Manusia mulai menggunakan akalnya untuk meneliti secara kritis segala sesuatu dalam kehidupannya termasuk dalam kehidupan bernegara. Adapun pemikiran tokoh-tokoh Aufklarung adalah Thomas Hobbes, John Locke D. Hume, Immanuel kant, Auguste Comte, William James.

Adapun Dinamika Pembelajaran sejarah merupakan bahwa pembelajaran adalah proses interaksi peserta didik dengan pendidik dan sumber belajar pada suatu lingkungan belajar. Pembelajaran merupakan bantuan yang diberikan pendidik agar dapat terjadi proses perolehan ilmu pengetahuan, penguasaan kemahiran dan tabiat, serta pembentukan sikap dan kepercayaan pada peserta didik. Dengan kata lain, pembelajaran adalah proses untuk membantu peserta didik agar dapat belajar dengan baik. menurut Taufik Abdullah pelajaran sejarah bukan rentetan peristiwa yang kering dan partikular tetapi sebuah wacana intelektual yang kritis dan rasional. Pembelajaran sejarah harus melalui tahapan sebagai berikut: (1) memupuk kesadaran sosial dan keakraban, (2) memperkenalkan makna dimensi waktu dalam dinamika kehidupan kepada siswa dan rasa hayat sejarah. Meteri pembelajaran sejarah jangan didominasi oleh sejarah politik melainkan sejarah sosial yang berisikan kreativitas lokal, (3) sejarah diajarkan sebagai kegiatan akademis untuk memahami jiwa dari sebuah perubahan.

\section{B. Saran}

Kita sebagai mahasiswa khususnya pendidikan sejarah seharusnya harus memahami tentang dinamika-dinamika pemikiran terhadap eropa selain itu kita juga harus mengetahui dinamika pembelajaran khususnya pembelajaran sejarah. Dari belajar sejarah kita bisa tahu tentang bagaimana suatu peristiwa itu penting untuk dijadikan pedoman. Oleh karena itu kita bisa mengambil pelajaran peristiwa sebagai pembelajaran sejarah tersebut untuk kehidupan yang akan datang agar lebih baik ke masa depannya. 


\section{DAFTAR PUSTAKA}

Arifin Anis, M. Z. (2013). Pelatihan Penyusunan Perangkat Pembelajaran.

Arifin Anis, M.Z. (2015). Sejarah Bukan Warisan Melainkan Pembelajaran.

Mata Pelajaran Sejarah Kurikulum 2013. Pelatihan Penyusunan Perangkat Pembelajaran Mata Pelajaran Sejarah Kurikulum 2013.

Syahda, S. T. SEJARAH SEBAGAI SUMBER PEMBELAJARAN SEJARAH.

Taufan Asfar (2019). Pendidikan Masa Renaisance: Pemikiran dan Pengaruh Keilmuan.

Kumalasari, Dyah (2008). Diktat Pengantar Pendidikan Sejarah I.

Karim, Abdul (2014). Sejarah Perkembangan Ilmu Pengetahuan. 